\title{
INTERAKSI MUSLIM DAN BUDHA DI DESA LUBUK MUDA
}

\author{
Rifni Juliasari \\ Hasbullah \\ Khairiah
}

UIN Sultan Syarif Kasim Riau

e-mail: khairiyah@uin-suska.ac.id

\begin{abstract}
Abstrak
Tulisan ini dilatarbelakangi oleh fenomena kehidupan antar umat beragama di Desa Lubuk Muda. Kajian tentang interaksi antar umat Islam dan Budha di Desa Lubuk. Muda meliputi potensi-potensi konflik yang mungkin ada dalam hubungan kedua kelompok agama tersebut yang dalam komposisi menempati persentasi utama dalam demografi Desa. Penelitian ini menggunakan metode kualitatif dengan mengandalkan observasi, wawancara dan dokumentasi sebagai teknik pengumpulan data dengan penetapan informan kunci yang terdiri dari tokob masyarakat dan tokoh agama baik dari kelompok. Islam maupun Budha. Lokasi penelitian adalab Desa Lubuk Muda Kecamatan Siak Kecil Kabupaten Bengkalis. Faktor-faktor pendukung dalam pola kerukunan antara umat Islam dan Budha di Desa Lubuk. Muda adalah sikap saling menghargai dan bertoleransi pada umat lain dalam pelaksanaan ibadah, adanya sikap saling menolong, sikap tidak memaksa umat lain untuk pindah ke salah satu agama, keikutsertaan dalam kegiatan sosial; gotong royong desa, musyawarah desa, saling menghadiri undangan pesta dan saling berbela sungkawa ketika salah satu kelompok sedang mendapat musibah, dan saling bekerjasama dalam bidang ekonomi untuk mensejabterakan penduduk. Desa Lubuk. Muda tanpa memandang golongan atau agama. Dari hasil penelitian yang telab dilaksanakan dapat disimpulkan bahwa pola interaksi umat beragama di Desa Lubuk. Muda adalab dalam bentuk agree in disagreement (setuju dalam perbedaan) serta tumbubnya solidaritas sosial yang kuat diantara mereka.
\end{abstract}

Kata Kunci; Interaksi, Kerukunan, Islam, Budha

\section{Pendahuluan}

Indonesia adalah bangsa dengan komposisi etnis yang sangat beragam. Begitu pula dengan agama, kepercayaan, bahasa, adat istiadat, orientasi kultur daerah, serta pandangan hidup. Dengan kata lain, bangsa Indonesia memiliki potensi, watak, karakter, hobi, tingkat pendidikan, warna kulit, status ekonomi, kelas sosial, pangkat dan kedudukan, varian keberagaman, cita-cita, orientasi hidup, loyalitas organisasi, kecenderungan dan afiliasi ideologis yang berbeda-beda .

Sebagai Negara hukum, bangsa ini juga mengatur tentang keberagaman budaya yang dimilikinya dalam upaya mencegah terjadinya konflik, seperti Hak Asasi Manusia mengenai agama, pemilihan pendidikan, berpendapat dan memilih tempat tinggal. Undang-undang juga

\section{I TOlernasI: media Komunikasi umat Beragama}

Vol. 11, No. 1, Januari - Juni 2019 
mengatur tentang kebebasan beragama terdapat padaPasal 29 UUD 1945 menegaskakan bahwa“ Negara berdasarkan Ketuhanan Yang MahaEsa” ( ayat 1 ). " Negara menjamin kemerdekaan tiap-tiap penduduk untuk memeluk agamanya masing-masing dan beribadat menurut agamanya dan kepercayaan itu" ( ayat 2 ). Seseuai dengan undang-undang tersebut ada enam agama yang diakui oleh Negara Indonesia yaitu: Agama Islam, Agama Hindu, Agama Budha, Agama Khatolik, Agama Protestan, Agama Kong $\mathrm{Hu}$ Chu.

Manusia sebagai makhluk sosial membutuhkan keberadaan orang lain dan hal ini akan dapat terpenuhi jika nilai-nilai kerukunan tumbuh dan berkembang ditengah-tengah masyarakat. Kerukunan antar-umat beragama didasarkan pada kebutuhan sosial, di mana satu sama lain saling membutuhkan agar kebutuhan hidup dapat terpenuhi. Kerukunan antarumat manusia pada umumnya, baik seagama maupun luar agama dapat diwujudkan apabila satu sama lain dapat saling menghormati dan menghargai .

Kerukunan adalah istilah yang dipenuhi oleh muatan makna baik dan damai. Intinya hidup bersama dalam masyarakat dengan kesatuan hati dan bersepakat untuk tidak menciptakan perselisihan dan pertengkaran. Kerukunan hidup antar-umat beragama sendiri berarti keadaan hubungan sesame umat beragama dilandasi toleransi, saling pengertian, menghargai kesetaraan dalam pengamalan ajaran agamanya dan kerjasama dalam kehidupan bermasyarakat, berbangsa dan bernegara. Kerukunan umat beragama sangatlah didambakan dan ingin direalisasikan di Negara ini. Baik dari tingkat pusat maupun provinsi atau kota. Hal ini diatur oleh struktur organisasi negara yang bernama Kemenag dan FKUB di seluruh wilayah Indonesia.

Kerukunan umat beragama dapat membangun sebuah Negara, dalam hal ini adalah negara Indoensia lebih maju. Banyak hal yang menguntungkan bagi Negara apabila masyarakatnya memiliki kehidupan yang rukun seperti, ekonomi Negara menjadi stabil dan meningkat karena dalam hal ini para pebisinis berkolaborasi untuk memasarkan produkproduk yang di usahakannya, tanpa memandang perbedaan agama atau suku.

Kemudian rasa toleransi masyarakat menjadi lebih tinggi seperti, saling tolongmenolong ketika terjadi kesusahan di salah satu pihak dan melakukan pembersihan atau menjaga keamanan tempat tinggal bersama-sama, tanpa ada memandang perbedaan agama atau suku. Hal lainnya yaitu fasilitas Negara tidak mudah hancur dan dana yang dimiliki Negara bisa untuk membangun infrastruktur lainnya. Hal ini seperti ketika terjadi sebuah konflik, masyarakat cenderung bersifat anarkis dan ingin menjatuhkan atau menghancurkan salah satu pihak contohnya dengan membakar tempat ibadah atau fasilitasfasilitas lainnya, yang mana untuk

\section{I TOleRAnsI: Media Komunikasi umat Beragama}


membangun suatu Negara harus mengeluarkan dana, dalam memajukan suatu bangsa salah satunya dengan meningkatkan dan bagusnya semuain frastruktur di setiap bidang. Suatu Negara tidak akan maju apabila yang dibangun hanya bangunan yang sama, seperti pembangunan tempat ibadah yang telah mengalami kerusakan akibat demostrasi yang anarkis.

Konflik keagamaan bisa diatasi dengan ikut menjalankan program pemerintah yang diusung dalam trilogy kerukunan, karena isi atau makna dari trilogy kerukunan itu membentuk suatu persatuan antara internal umat beragama, antar-umat beragama dan antar-umat beragama dengan pemerintah. Salah satu tempat yang telah berhasil menghidupkan trilogy kerukunan dalam kehidupan bermasyarakatnya bisa kita lihat di Provinsi Riau Kabupaten Bengkalis Kecamatan Siak Kecil Desa Lubuk Muda. Wilayah ini memiliki masyarakat yang mampu menghidupkan kerukunan umat beragama di dalam kehidupan sehari-hari. Desa yang ditinggali oleh beberapa penganut agama, seperti Islam, Budha dan Khatolik, dalam keseharian mereka menjalankan kehidupannya dengan damai dan harmonis di tengah-tengah perbedaan yang ada antara satu umat dengan umat yang lainnya.

Diantara agama-agama yang ada, terdapat dua penganut agama yaitu Islam dan Budha yang merupakan jumlah penduduk yang dominan di desa Lubuk
Muda ini, namun dalam menjalankan hubungan sosial mereka tidak pernah mengalamikonflik. Tidak menutup kemungkinan potensi-potensi konflik juga hadir dalam kehidupan sehari-hari masyarakat Desa Lubuk Muda, akan tetapi perbedaan-perbedaan yang hadir, bisa mereka sikap idenganbaik. Potensi-potensi konflik muncul dar iadanya perbedaan makna dan pemahaman masingmasingpihak tentang suatu objek. Seperti pemeliharaan anjing bagi umat yang beragama Budha sebagaialat bantunamun bagi umat beragama Islam akan membahayakan keselamatan, karena hewantersebutmengejardanmenggigitman usia.

Potensi-potensi konfliki ni bias di atasi dengan menghadirkan sikap saling tolong-menolong dalam kehidupan seharihari, saling menghormati, yang mana pada peringatan hari raya mereka saling mengunjungi dengan sikap yang hangat dan ramah tamah, saling peduli dan memiliki sikap keterbukaan dan kemudian di segi lain masyarakat Desa Lubuk Muda juga saling berbagi seperti makanan dan pakaian tanpa memandang perbedaan agama.

Kerukunan yang diinginkan pemerintah seperti yang diusung dalam trilogi kerukunan telah terealisasikan di Desa Lubuk Muda, hal ini terbukti dari terciptanya semua point-point kerukunan yang terdapat pada butir-butir trilogi kerukunan. Salah satu contoh kerukunan antar-umat beragama tersebut seperti 
dekatnya rumah ibadah umat Islam dan umat Budha Tridharma yang ada di Desa Lubuk Muda tidak menjadi kendala dalam menghidupkan kerukunan umat beragama dan tidak membuat mereka mengalami konflik walaupun terkadang mengadakan acara keagamaan dalam waktu yang bersamaan.

Pola yang ditanam pada masyarakat Desa Lubuk Muda dalam menjaga kerukunan umat beragama yaitu dengan menumbuhkan sikap saling menghormati tanpa menggangu akidah masing-masing serta memiliki sikap keterbukaan satu sama lain.

Ciri lain dari pola kerukunan yang terjadi di Desa Lubuk Muda yaitu pada kegiatan rewang. Rewang yang dilakukan di Desa Lubuk Muda tidak memandang agama dan suku dari masyarakat setempat, apabila yang memiliki hajat umat Islam maka umat Budha yang berada di sekitar tempat yang sedang mengadakan hajatan tersebut pasti ikut melaksanakan rewang.

Interaksi yang terjadi ketika rewang tersebut menghasilkan kerukuna nantarumat beragama. Di sinilah gambaran sikap saling tolong-menolong, keterbukaan itu dapat terlihat pada masyarakat di Desa Lubuk Muda. Beberapa pola atau model tingkah lakuma syarakat di Desa Lubuk Muda yang dibangun dalam menciptakan suasana rukun dan damai dapat menjadi contoh danacuanbagidaerah yang masih mengalami konflik antar-umatberagama, agar

bias terciptanya kehidupan masyarakat yang harmonis, saling tolong-menolong dan tidak saling bermusuhan supaya agama bias menjadi pemersatu bangsa Indonesia yang secara tidak langsung memberikan stabilitas dan kemajuan negara.

\section{Kerukunan dalam Islam}

Sesuai dengan hakekat penciptaannya (oleh Allah SWT) manusia mempunyai kecenderungan kepada agama, dengan posisi agama yang begitu kokoh dalam diri manusia maka kerukunan hidup dalam menjalankan ajaran agamanya amatlah penting. Ketiadaan kerukunan dalam beragama gaibnya akan mendatangkan kegelisahan yang bisa bermuara kehidupan yang sia-sia. Pandangan tentang kerukunan yang diajarkan oleh agama Islam terhadap umat-umat agama lain, seperti termaktub dalam surat Al-Kafirun:

Artinya: “( 1 ) Katakanlah ( Muhammad ), Wahai orang-orang kafir! ( 2 ) aku tidak akan menyembah apa yang kamu sembah ( 3 ) dan kamu bukan penyembah apa yang aku sembah (4) dan aku tidak pernah menyembah apa yang kamu sembah ( 5 ) dan kamu tidak pernah ( pula ) menjadi penyembah apa yang aku sembah, ( 6 ) Untukmu agamamu dan untukku agamaku ."

Khusus dalam hubungan antar agama dan hubungan antar-umat beragama, jika kita mengacu pada firma allah " lakum dinukum waliyadin "( bagimu agama dan bagiku agamaku ), jelas

\section{I TOleransI: media Komunikasi umat Beragama}

Vol. 11, No. 1, Januari - Juni 2019 
Islam mempersilahkan orang lain atau sekelompok orang lain untuk menganut agama non-Islam. Tidak masalah apabila seseorang atau sekelompok orang menganut agama non-Islam. Islam sangat melarang penganutnya untuk mengusik, mengganggu, mencela, meneror, atau menyerang seseorang atau sekelompok orang yang memeluk agama non-Islam. Ajaran islam " lakum dinukum waliyadin " ( bagimu agamamu dan bagiku agamaku ) sebagai landasan strategis penerapan prinsip "agree in disagreement" ( setuju untuk tidak setuju ) dalam hubungan antar agama dan hubungan antar-umat beragama .

Prinsip sepakat untuk tidak sepakat merupakan prinsip dasar Islam yang menghormati kebebasan beragama sekaligus menjelaskan bahwa Islam sangat menghargai dan menjunjung tinggi toleran terhadap komunitas-komunitas agama non-Islam. Umat Islam mengakui “ keberadaan"( bukan kebenaran ) agama lain atas dasar prinsip kebebasan beragama dan sikap toleran komunitas-komunitas agama non-Islam. Menurut ajaran Islam sikap tidak toleran, sikap fanatik dan intoleransi dalam segala bentuk manifestasinya adalah perbuatan yang sangat tercela (merupakan dosa moral, dosa sosial dan dosa kultural) karena bertentangan dengan nilai-nilai ajaran Islam dan bertentang pula dengan asasasas hukum demokrasi dan HAM. Ayat lain yang juga menjelaskan tentang kerukunan dalam Islalm juga dijelaskan pada surat Ali-Imran 3: 64 berikut ini :

Artinya: "Katakanlah: hai ahli kitab, marilah (berpegang) pada suatu kalimat (ketetapan) yang tidak ada perselisihan antara kami dan kamu, bahwa tidak kita sembah kecuali Allah dan tidak dipersekutukan. Dia dengan sesuatupun dan tidak (pula) sebagian kita menjadikan sebagian yang lain menjadikan Tuhan selain Allah". Jika mereka berpaling maka katakannlah kepada mereka: “ saksikanlah, bahwa kami adalah orang-oramg yang berserah diri (kepada allah" (QS.

Kemudian dalam surat Al-Maidah 5: 48.

Artinya: "Dan sekiranya Allah menghendaki, niscaya kamu dijadikan-Nya satu umat (saja), tetapi Allah hendak memuji kamu terhadap pemberian-Nya kepadamu, maka berlomba-lombalah dalam berbuat kebajikan. Hanya kepada Allah lah kamu kembali semuanya, lalu diberikan-Nya kepadamu apa yang telah perselisihkan itu ."

Surat Al-Imran ayat 3:64 menunujukan bahwa umat Islam diminta untuk mengajak ahli kitab kepada ajaran yang umum antara agama Islam dan agama-agama yang lain, yakni menyembah Allah SWT. Sedangkan surat Al-Maidah 5:48 menunujukkan bahwa agama diantara umat manusia merupakan bagian dari kehendak Allah .

Dalam sejarah Islam, sikap menghargai atau kerukunan telah lama

\section{I TOleransI: media Komunikasi umat Beragama}


diperatikkan Nabi Muhammad SAW. Dengan konsep kebersamaannya ia telah lama mampu meredam ketegangan dan konflik berkepanjangan antara suku di Madinah .

Dalam Islam tidak dibenarkan memaksa kebenaran pada umat agama lain (Q.S Al-Baqarah 256). Ajaran Islam melarang umatnya mempengaruhi siapapun untuk masuk Islam, apalagi dalam bentuk tekanan-tekanan sosial dan politik. Umar Bin Khattab sering mempengaruhi budaknya, Astiq non Islam untuk menerima Islam. Akan tetapi ketika budaya menolak, Umar hanya dapat berucap: "La ikraha fial-din" (tidak ada paksaan dalam agama Islam".(

Islam juga melarang Bahasa kasar kepada umat agama lain, sebagai mana tertuang dalam surat Al-An'am 6: 108 :

Artinya: " Dan jangan lah kamu memaki sembahan-sembahan yang mereka sembah selain Allah karena mereka akan memaki Allah dengan melampaui batas tanpa pengetahuan ".

Dalam hubungan ini, diperlukan pikiran yang jernih dan sikap kritis dari semua pihak (non-muslim) untuk bisa memilah, memisahkan dan membedakan antara perilaku (sebagian) orang Islam sebagai doktrin sama sekali tidak mengajarkan kekerasan, teror dan kebiringisan. Tidak ada doktrin dalam
Islam, baik secara eksplesit maupun secara implisit, yang mengajarkan terorisme, brutalisme, anarkisme, perusakan, pembakaran ataupun tindakan kekerasan (violence) terhadap komunitas baik yang seagama maupun yang tidak seagama. Dengan kata lain, terorisme, brutalisme, anarkisme dan segala bentuk aksi kekerasan lainnya sebenarnya tidak ada kaitannya sama sekali dengan ajaran Islam .

Adalah cara pandang dan logika yang amat salah, jika misalnya ada sekelompok muslim yang melakukan kekerasan atas nama agama lantas disimpulkan bahwa Islam mengajarkan kekerasan. Penyebab menculnya fundamentalisme, anarkisme dan radikalisme (bahkan terorisme) dikalangan sekelompok muslim (dan juga di kalangan para penganut agama-agama lain) harus secara cermat dan kritis dicari dari variable sosial politik dan faktor lain di luar ajaran agama. Biasanya, penyebab munculnya fundamentalisme, radikalisme, brutalisme dan anarkisme (bahkan teroris) dipicu oleh masalah ideologis-politis (perlakuan rezim yang tidak adil terhadap kelompok tertentu), penafsiran parsial dan yidak proposional terhadap teks-teks kitab suci serta faktpr kesenjangan sosial ekonomi .

Pola kerukunan dalam Budha

Iman tidak di temukan dalam ajaran Budha karena ajaran Budha menekankan pada pemahaman. Iman akan membius fikiran dan emosional dan meminta kepercayaan akan hal-hal yang tidak dapat

\section{I TOleransI: Media Komunikasi umat Beragama}

Vol. 11, No. 1, Januari - Juni 2019 
diketahui. Pengetahuan menghancurkan Iman dan Iman menghancurkan menhanvurkan dirinya sendiri jika kepercayaan misterius di uji dibawah cahaya terang akal budi. Keyakinan diri tidak diperoleh dengan Iman karena Iman tidak menekankan pada akal budi. Voltaire berkata, “ Iman adalah percaya akan sesuatu yang menurut akal budimu hal itu tidak benar; karena jika akal budi-mu menyetujuinya, tidak akanada pertanyaan tentang Iman buta ."

Konsep kerukunan yang diusung sebagai penduan umat Budha adalah:

1. Kerukunan sesama umat Budha dalam satu Vihara;

2. Kerukunan sesama umat Budha dalam sekte-sekte; dan

3. Kerukunan umat Budha dengan sesama umat beragama lainnya.

Rumusan kerukunan yang dijadikan panduan sebagai konsep bagi umat Budha dalam berinteraksi sosial direalisasikan dalam kegiatan-kegiatan konkrit melalui berbagai bentuk dan cara dalam program keagamaan di Vihara. Konsep kerukunan tersebut berdasarkan pada ajaran Sang Budha Sakyamuni yang berintikan "cinta kasih". Oleh karena itu, bagi umat Budha dibebankan untuk mengajarkan cinta kasih sesama manusia sekaligus mewujudkan dalam bentuk dharma yang bersendikan Panca Dharma melaui 8 jalan .

Perhatian utama Sang Budha dalam kehidupan ini adalah untuk mengobati penderitaan sebagai penyakit batin umat manusia. Sang Budha mengajarkan kepada kita kasih sayang diantara sesama makhluk hidup .

Beliau memberi teladan tentang bagaimana kehidupan yang baik dan benar di tengah-tengah kehidupan masyarakat, yaitu:

1. Berbuat baik dalam pikiran, ucapan dan tindakan,

2. Melakukan kegiatan untuk kepentingan orang banbyak,

3. Taat dan hormat kepada pimpinan atau orang yang lebih tua,

4. Melenyapkan ketakutan didalam masyarakat, melindungi mereka yang perlu dilindungi, menyediakan kebutuhan sehari-hari, hidup sederhana dan penuh cinta kasih,

5. Mempelajari ilmu pengetahuan dan kesenian, mendatangi dan belajar dari orang-orang suci,

6. Hudup tenang, tanpa amarah dan mencari kesalahan orang lain,

7. Merukunkan golongan-golongan dalam masyarakat untuk hidup bersama secara serasi dan harmonis,

8. Dapat memahami, meneliti dan memilah-milah watak-watak orang berbeda,

9. Memperhatikan kepentingan, kesejahteraan, keamanan dan kemantapan masyarakat, 
10. Memikirkan bagaimana meningkatkan kepercayaan, moral, pendidikan, kemurahan, kelurusan dan kecerdasan,

11. Dengan batin yang tulus, terbuka dan luhur menatap orang dengan pandangan penuh cinta kasih dan membuang kebiasaan-kebiasaan buruk dan cara penghidupan salah,

12. Menolak segala macam penipuan dan perlakuan tidak adil serta segala tindakan kekerasan .

Sang Budha bersabda dalam kitab Samyutta Nikaya I,hal 89 sebagai berikut:

"untuk bergaul dan bersahabat dengan apa yang benar dan baik.... Engkau sendirilah yang harus tekun menjalankan kebaikan”....

Bilamana seseorang menghargai hidupnya, ia harus menjaganya baik-baik dan hidup sampai pada pengertian penuh tentang empat kebenaran muia, yang merupakan dasar semua kepercayaan Budha, yang mana empat kebenaran mulia itu adalah: pertama, sepanjang hidupnya manusia mengalami penderitaan itu dan mengatasinya. Kedua, penyebab penderitaan adalah keinginan manusia yang kuat akan hidup, kesenangan dan uang. Ketiga, menyingkirkan keinginan yang kuat berarti menyingkirkan penderitaan. Keempat, jalan tengah antara askese dan hendonisme satu-satunya jalan menghilangkan keinginan yang kuat itu .
Dengan cara menyingkirkan kesenangan diri dan ketertarikan pada duniawi. Lingkaran, kelahiran, kehidupan dan kematian akhirnya dapat dipecahkan. Hal ini dapat dicapai dengan cara mengikuti jalan berjalur Delapan yaitu:

Pertama, mengerti empat kebenaran mulia dengan benar. Kedua, berfikir yang benar, bahkan juga kepada kehidupan yang tingkatannya paling rendah sekalipun. Ketiga, berbicara yang benar dengan tujuan yang murni, mulia dan baik. Keempat, berbuat yang benar, menyangkut tindakan yang bermoral, penuh perhatian kepada sesama dan melakukan kebaikan terhadap semua makhluk hidup. Kelima, mata pencaharian yang benar, ialah supaya umat Budha jangan mencari mata pencaharian dari hal-hal yang mengakibatkan kekerasan atau mengikuti ajaran Agamanya; rahib Budha harus diurus oleh umat Budha. Keenam, usaha yang benar untuk mengusir semua fikiran jahat. Ketujuh, perhatian yang benar, yang menyangkut kesadaran terhadap kebutuhan- kebutuhan orang lain. Kedelapan, kosentrasi yang benar dengan menggunakan meditasi, yang dapat menciptakan ketenagan batin seseorang dan rasa damai dengan diri sendiri maupun dengan dunia .

Sang Budha bersabda; untuk membina kebersamaan dan keharmonisan hidup, seseorang harus mengembangkan jiwa kasih dalam perbuatan sehari-harinya. Ada 6 kebenaran Dharma untuk membina kerukunan dan kedamaian tersebut : 
1. Senantiasa memancarkan kasih dalam kehidupan sehari-hari melalui tindak perbuatan,

2. Mengembangkan kasih melalui ucapan,

3. Mengembangkan kasih melalui pikiran,

4. Mengembangkan kasih dengan membagi berkah kasih kepada orang lain,

5. Mengembangkan kasih kepada orang yang bermoral dalam masyarakat,

6. Mengembangkan kasih pada pandangan yang sama, pandangan hidup dalam hidup berbangsa, bernegara, dengan satu tujuan.

Enam kebenaran inilah yang dapat menghindari perepcahan konflik antarumat, terbina kerukunan hidup, saling menghormati, mencintai, menghargai dan dapat menunjang persatuan dan kesatuan .

\section{Kerukunan Umat Islam dan Budha di} Desa Lubuk Muda Kecamatan Siak

\section{Kecil Kabupaten Bengkalis}

1. Toleransi dalam Melaksanakan Ibadah

Toleransi dalam melaksanakan ibadah di sini maksudnya ialah memberi tenggang rasa kepada umat agama lain untuk melaksanakan ibadahnya, tanpa harus mengikuti dan membantu melaksanakan ritual atau upacara keagamaan yang dilakukannya. Pola kerukunan umat Islam dan Budha di Desa Lubuk Muda terbina dan berjalan dengan adanya sikap masyarakat Lubuk Muda yang toleransi kepada umat yang berbeda agama dalam melaksanakan ibadah. Sikap toleransi kepada setiap umat beragama dalam melaksanakan ibadah ini, merupakan faktor pertama dalam terciptanya kerukunan umat beragama di Desa Lubuk Muda Kecamatan Siak Kecil. Hal ini direalisasikan oleh semua kalangan masyarakat Lubuk Muda baik yang muda maupun yan tua tanpa memandang status sosial dan lainnya. Kerukunan umat beragama akan terjaga dengan baik apabila masing-masing pihak bisa menjalankan ibadahnya dengan tenang tanpa adanya gangguan dari pihak lain.

Tidak ada masyarakat Lubuk Muda yang memilikki sikap truth claim yang terlalu fanatik sehingga menyalahkan dan menghalang umat lain untuk beribadah. Keterangan yang diberikan responden salah satunya mengenai menumbuhkan sikap toleransi antarumat beragama dalam menjalankan ibadahnya masing-masing seperti hasil wawancara bersama Ustad Rozak berikut ini:

"Sikap toleransi dan saling menghargai umat agama lain dalam melaksanakan ibadahnya harus ada kita semua dan Alhamdulillah sikap ini tumbuh pada setiap masyarakat Desa Lubuk Muda. Sikap inilah yang akan menghasilkan kerukunan antar-umat beragama seperti yang kita rasakan di desa ini. Kita tidak boleh mengganggu ataupun 
melarang umat agama lain untuk melaksanakan ibadahnya selagi mereka tidak mengganggu agama kita."

Dari hasil wawancara dan observasi, penulis menemukan bahwa umat Islam dan Budha Desa Lubuk Muda bersikap saling menghargai dan memberi toleransi kepada siapapun diantara mererka yang ingin melaksakan ibadah menurut kepercayaab masing-masing. Kemajemukan ini hadir diharapkan sebagai salah satu asset dalam memperkarya kebudayaan negara ini, untuk itu perlu ditumbuhkan sikap saling menghargai dan toleransi antar sesame umat.

Sebagaimana firman Allah dalam Q.S Al-An'am 6: 108 yakni:

Artinya: "Dan jangnlah kamy memmaki sembahan-sembahan yang mereka sembah selain Allah karena mereka nanti akan memaki Allah dengan melampaui batas tanpa pengetahuan."

Maksud dari ayat tersebut dapat disimpulkan bahwasannya bagi penganut agama Islam dilarang untuk menghina ataupun mengganggu agama lain. Masyarakat Desa Lubuk Muda Kecamatan Siak Kecil Kabupaten Bengkalis, dalam kehidupan sehariharinya mereka bisa rukun dan damai, dengan dasar saling menghargai dan memberi toleransi kepada umat agama lain dalam menjalankan ibadahnya. Adanya toleransi dalam menjalankan ibadaha bagi masing-masing umat beragama inilah, yang menjafi salah satu perekat kemajemukan masyarakat Desa Lubuk Muda. Adapun sikap toleransi masyarakat Desa Lubuk Muda Kecamatan Siak Kecil dalam melaksanakan ibadah yaitu sebagai berikut:

Berikut ini hasil observasi di lapangan tentang sikap umat muslim dalam memberi toleransi menjalankan ibadah kepada umat Budha, ketika umat Budha melaksanakan sembahyang di kelenteng, umat muslim menyikapinya dengan baik dan penuh toleransi tanpa ada mengusik masyarakat Budha yang sedang melakukan ibadah di kelenteng. Letak antara kelenteng dan musholla tidak terlalalu jauh, namun tidak ada kesenjangna-kesenjangan yang terjadi antara dua agama ini. Tidak ada yang merasa keberatan dari salah satu pihak, baik budha ataupun muslim apabila akan melaksanakan acara keagamaan disalah satu rumah ibadah tersebut.

Ketika umat Budha melaksanakan sembahyang du rumah, umat muslim menyikapinya dengan baik dan toleransi walaupun keadaan rumah penduduk di Desa Lubuk Muda memeiliki jarak yang tidak terlalu jauh antara rumah penduduk Budha dan Islam. Ketika umat Budha melakukakn 
pemujaan kepada roh-roh yang ada di jalan, muslim menyikapinya penuh toleransi, dengan tidak melarang umat Budha untuk menjalankan upacara keagamaan yang di yakininya walaupun pada proses pemujaan roh-roh di jalan tersebut mengggunakan sesajen dan lilin yang diletakkan di pinggiran jalan.

Ketika umat Budha melaksanakan upacara kematian, umat muslim Desa Lubuk Muda bisa menghirmati dan memberi toleransi dan ketika umat BUdha melaksanakan upacara untuk para arwah, umat muslim tidak menentang dan mengganggu umat Budha yang hendak melaksanakan upacara untuk para arwah yang mana pada saat itu dilakukan pembakaran barang-barang kebutuhan untuk paara arwah yang berbentuk miniature, sebagai tabda pengiriman kepada arwah tersebut.

Berikut ini hasil observasi di lapangan tentang sikap umat Budha dalam memberi toleransi menjalankan ibadah kepada umat Muslim, ketika umat muslim melaksanakan sholat lima waktu dengan membunyikan azan di masjid dan musholla, umat Budha meresponnya dengan baik dan tidak merasa keberatan dengan azan yang dibunyikan ketika sholat lima waktu. Ketika umat muslim melaksanakan tadarus pada setiap malam setelah sholat terawih di Bulan Rhamadan dengan menggunakan pengeras suara dan Takbiran ketika perayaan Idul Fitri dan Idul Adha, umat Budha menyikapinya dengan baik dan penuh dengan toleransi. Umat Budha tidak merasa terganggu dengan bunyi takbir yang dikumandangkan ketika umat Muslim merayakan Idul Fitri dan Idul Adha. Teerakhir yaitu ketika umat Muslim melaksanakan penyembelihan hewan qurban, umat Budha menyikapinya dengan baik dan penuh toleransi tanpa merasa terganggu dengan pelaksanaan penyembelihan hewan qurban, pada pembagian hewan qurban masyarakat Budha juga mendapatkan bagian dari hewan qurban tersebut.

2. Menyakini Agama Sendiri dan Menghargai Agama Oran Lain

Pola kerukunan umat Islam dan umat Budha di Desa Lubuk Muda Kecamatan Siak Kecil, salah satunya dengan terbinanya dan menumbuhkan sikap meyakini agama sendiri dan menghargai agama orang lain. Sikap ini bisa tumbuh pada masyarakat Desa Lubuk Muda karena pada masingmasing individu menyakini dengan sungguh-sungguh dan mengetahui ajaran-ajaran tentang kerukunan yang diajarkan oleh masing-masing agama yang dianutnya, sehingga dapat memahami batas-batas dalam bertindak di lingkungan masyarakat, sebagaimana yang dikatakan oleh salah satu tokoh agama Budha Desa Lubuk Muda: 
"kita sebagai umat beragama hendaknya saling bersikap baik dan sopan, karena pada dasarnya di setiap agama itu mengajarkan tentang kerukunan dan kebaikan kepada semua orang, tidak ada agama yang mengajarkan tentang keburukan ataupun kejahatan. Hanya saja dalm mengungkapkan ajaran tentang kebaikan itu berbeda-beda ."

Dari data wawancara dan observasi di atas dapat penulis simpulkan, bahwa sikap menyakini agama sendiri dan menghargai agama orang lain ini memang berjalan dengan baik di Desa Lubuk Muda Kecamatan Siak Kecil Kabupaten Bengkalis. Hal ini terlihat dari tidak ada umat Islam dan Budha di Desa Lubuk Muda yang merasa terganggu dengan perbedaan, baik dalam cara beribadah maupun keseharian.

Konteks ini yang petut dipahami bahwa persatuan yang diajarkan itu tidak melebur perbedaan, tetapi tetap menghormati perbedaan, karena setiap kelompok telah memilih jalan dan tatanan hidup mereka, sehingga mereka harus berpacu mencapai prestasi kebajikan. Hal inin sebagaimana dalam Al-Qur'an, bahwa:

\begin{tabular}{lcr}
\multicolumn{1}{c}{ Artinya: } & "Dan kami & telah \\
menurunkan & kitab & (Al-Qur'an) \\
kepadamu & (Muhammad) & dengan \\
membawa & kebenaran, & yang \\
membenarkan & kitab-kitab & yang
\end{tabular}

diturunkan sebelumnya dan menjaganya, maka putuskanlah perkara mereka menurut apa yang diturunkan Allah dan janganlah engkau mengikuti keinginan mereka dengan meninggalkan kebenaran yang telah datang kepadamu. Untuk tiap-tiap umat antara kamu, kami berikan aturan dan jalan terang. Sekiranya Allah meghendaki, niscaya kamu dijadikanNya satu umat saja, tetapi Allah hendak menguji kamu terhadap pemberianNya kepadamu. Maka berlombalombalah berbuat kebaikan. Hanya kepada Allah kamu semua kembali, lalu beritahukan-Nya kepadamu terhadap apa yang dahulu kamu perselisihkan". (Q.S. Al-Maidah.48)

Khusus dalam hubungan antar agama dan hubungan antar-umat beragama, jika kita mengacu pada firman Allah "lakum dinukum waliyadin" (bagimu agamamu bagiku agamaku), jelas Islam mempersilahkan orang lain atau sekelompok orang lain untuk menganut agama non-Islam. Tidak masalah apabila seseorang atau sekelompok orang menganut agama non-Islam. Isalam sangat melarang penganutnya untuk mengusik, menggaggu, mencela, meneror, atau menyerang seseorang atau sekelompok orang yang memeluk agama non-Islam. Ajaran Islam " lakum dinukum waliyadin" ( bagimu agamamu bagiku agamaku) merupakan landasan strategis penerapan prinsip "agree in 
disagreement" (setuju atau tidak setuju) dalam hubungan antara agama dan hubungna antar-umat beragama.

Prinsip sepakat untuk tidak sepakat merupakan prinsip dasar Islam yang menghormati kebebasan beragama dan sekaligus menjelaskan bahwa Islam sangat menghargai dan menjunjung tinggi toleran terhadap komunitaskomunitas agama non-Islam. Umat Islam mengakui"keberadaab" (bukan kebenaran) agama lain atas dasar prinsip kebebasan beragama dan sikap toleran terhadap komunitas-komunitas agama non-Islam. Menurut ajaran Islam, sikap toleran, sikap fanatik, dan intoleransi dalam segala bentuk dan manifestasinya adalah perbuatan yang sangat tercela (merupakan dosa moral, dosa sosial dan dosa kultural) karena bertentangan dengan nilai-nilai ajaran agama Islam dan bertentangan pula dengan asas-asas hukum, demokrasi dan HAM. Adapun sikap masyarakat Desa Lubuk muda dalam menyakini agama sendiri dan menghargai agama orang lain yaitu sebagai berikut:

Berikut ini hasil observasi di lapangan tentang sikap umat Muslim dalam menyakini Agama sendiri dan menghargai agama orang lian, ketika umat Budha membakar kertas sembahyang did epan rumahnya, umat Muslim tidak ikut membantu umat Budha tersebut dalam membakar kertas. Walaupun kegaiatan yang dilakukan hanya membakar kertas, umat Muslim di Desa Lubuk Muda menyadari bahwa apa yang dilakukan umat Budha tersebut memiliki nilai pemujaan atau sesembahan. Sikap yang di tunjukkan umat Islam kepada umat Iskam kepada umat Budha mempersilahkan dia melakukan apa yang diyakkini dan tidak ikut melakukan apa yang dia lakukan umat Budha tersebut. Ketiks umat Budha memasang di tokonya patung kucing yang bergerak dan seakan memanggil yang melihatnya. Sikap yang di tunjukkan Islam ke umat Budha, yaitu menghargai dengan cara tidak memprotes apa yang dipajang umat Budha tersebut, hal ini sebagai bentuk dari sikap menghargai atas apa yang di yakini. Patung kucing tersebut di yakini umat Budha dapat memanggil pembeli aka tetapi pedagang-pedagang Muslim yang ada di Desa Lubuk Muda tidak mengikutinya.

Sedangkan bentuk sikap umat Budha dalam menyakini Agama Sendiri dan Menghargai Agama Orang Lain, adalah sebagai berikut:

Berikut ini hasil observasi di lapangan tentang sikap umat Budha dalam menyakini agama sendiri dan menghargai agama orang lian, ketika umat Islam melaksanakan puasa di bulan Rhamadan umat Budha sekitar memberi respon kepada umat Islam dengan tidak makan atau minum di depan umat Islam yang sedang berpuasa. Sikap ini adalah acara umat 
Budha menghargai umat Islam yang sedang melaksanakan ibadah puasa dalam hal ini tidak ada dari umat Budha yang mengajak untuk membatalkan puasa. Ketika umat Islam melakukakn takbir keliling desa malam peringatan lebaran Idul Fitri dan Idul Adha, denan rombongan yang cukup damai yang dilengkapi beduk dan pengeras suara, tidak ada pada saat itu umat Budha yang merasa terganggu dengan kemeriahan yang dibuat oleh umat Budha pada saat memberi respon dengan mengucapkan selamat dan menyaksikan umat Islam yang sedang pawai.

Agama ialah suatu jenis sistem sosial yang dibuat ole penganut-penganutnya yang berporos pada kekuatan-kekuatan non empiris yang dipercayainya dan didayagunakannya untuk mencapai keselamatan bagi diri mereka dan masyarakat luas umumnya. Hal ini tumbuh di Desa Lubuk Muda dengan masyarakat yang ada menerapkan sikap menyakini agama sendiri dan menghargai agama orang lain.

3. Kebersamaan dalam Peristiwa Sosial

Pola kerukunan umat Islam dan Budha di Desa Lubuk Muda di tandai dengan adanya sikap kebersamaan dalam peristiwa sosial, kepada semua masyarakat yang ada di Desa Lubuk Muda tanpa memandang perbedaan agama maupun status sosialnya.
Sebagaimana yang dikatakan oleh warga Desa Lubuk Muda berikut ini:

"Sebagai masyarakat Desa Lubuk Muda yang hidup disatu wilayah yang sama harus memiliki sikap saling menghargai dan ramah tamah dalam bertetangga, karena kita adalah saudara satu desa walupun agama maupun kebudayaan kita berbeda beberapa masyarakat yang ada disini ."

"Perbedaan agama tidak menjadi penghalang untuk kita bersikap menghargai milik oramg lain dan beramah tamah kepada orang yang tidak seagama dengan kita, karena kita adalah saudara satu desa walaupun terdapat perbedaan, seperti perbedaan agama ."

"Dalam hal berteman tidak ada batasan antara umat Budha dan umat Muslim, untuk mengerjakan tugas-tugas sekolah yang diberikan biasanya kami mengerjakan dengan cara berkelompok dengan tetanggatetangga yang dekat dan seleting, baik yang Budha atau pun teman dari Muslim .”

Dari hasil wawancara dan observasi dapat penulis simpulkan, bahwa setiap masyarakat Desa Lubuk Muda memeiliki rasa solidaritas yang tinggi satu sama lain tanpa memandang agama seseorang ataupun status sosialnya sehinga hal ini menghasilkan sikap saling menghargai dan ramah 
tamah dalam menjalankan kehidupan bermasyarakat. Sikap interaksi yang ramah tamah dan baik berjalan dengan adanya perkumpulan-perkumpulan masyarakat Desa Lubuk Muda ketika ada rewang di salah satu masyarakat yang memiliki hajat, saling mengundang dan menghadiri ketika ada pesta atau pun dalam peringatan hari raya keagamaan mereka saling membantu dan berkunjung.

Sikap slaing terbuka dan memiliki rasa persaudaraan yang menjadi ciri khas kerukunan masyarakat Desa Lubuk Muda ini, di mana masyarakat meyakini dengan memiliki keterbukaan satu sama lain akan mencegah rasa kecurigaan yang dapat membuat perselisihan. Sikap kebersamaan dalam peristiwa sosial masyarakat Desa Lubuh Muda Kecamatan Siak Kecik dalam berinteraksi antar-umat beragama di tunjukkan melalui respon masyarakat sebagai berikut:

Berikut ini hasil observasi dilapangan tentang sikap umat Budha dalam kebersamaan peristiwa sosial. Menjenguk orang sakit, ketika ada tetangga dari umat Islam yang sakit, umat Budha menyempatkan waktunya untuk menjenguk tetangganya yang sakit. Kemudian proses jual beli yang berjalan dengan baik, umat Budha mau bebelanja dan menjualkan dagangannya ketempat umat Islam.
Sikap ramah tamah juga bisa dilihat dari kegiatan rewang. Pada saat membantu dalam mempersiapkan acara pernikahan umat Islam, umat Budha juga ikut berpartisipasi acara pernikahan umat Islam, umat budha juga ikut berpartisipasi dalam mempersiapkannya, hal yang dilakukan seperti membantu membuat tenda. Menghadiri undangan juga sebagai bentuk saling menghormati yang mana masyarakat Budha bersedia meluangkan waktunya untuk hadir di undangan umat Islam. Sikap saling menghargai dan ramah tamah juga ditunjukkan daei mengundang ketika ada acara, umat Budha ketika memiliki acara seperti pernikahan ataupun ulang tahun anaknya juga mengundang umat Islam.

Pada saat ada kegiatan gotong royong umat Budha juga mengikuti dalam pelaksanaan gotong royong tersebut. Inilah salah satu tempat berinteraksi yang bagus antar satu dan lainnya karena saat gotong royong ratarata masyarakat pada berkumpul pada satu tempat dan kegiatan sama. Pada saat ada kemalangan di umat Islam, umat Budha mau membantu masyarakat yang sedang tertimpa musibah tersebut. Umat Budha tidak keberatan membantu umat Islam yang sedang tertimpa musibah, seperti memberi pakaiaan ataupun uang kepada umat Islam yang sedang tertimpa musibah (kebakaran rumah). 
Dalam menyikapi perayaan hari besar agama, umat Budha menyikapi perayaan agama umat Islam dan memberikan ucapan selamat lebaran serta memberi beberapa THR, seperti minuman atau kue lebaran. Umat Budha memiliki sikap ramah dan mau bertegur sapa dalam kehidupa seharihari, untuk mengakrabkan antara umat Budha dan Islam, di waktu sore mereka terkadang mengobrol ringan di depan rumahnya.

Tugas sekolah juga menjadi bentuk dari sikap ramah tamah yang terlihat di Desa Lubuk Muda, hal ini terlihat dari kerjasama dalam mengerjakan tugas sekolah, anak-anak dari umat Budha dan Islam saling bekerjasama dalam menyelesaikan tugasnya, tidak ada larangan dari orang tua mereka walaupun mereka berbeda agama, di saat kerjasamamenyelesaikan tugas sekolah mereka saling mengunjungi rumah, seperti umat Islam mengerjakan tugas kelompoknya kerumah umat Budha begitu juga sebaliknya.

Berbagi makanan dan pakaian juga menjadi bentuk dari sikap ramah di Desa Lubuk Muda, dalam kehidupan sehari-hari apabila umat Budha memeiliki lebih dalam makanan ataupun pakaian, mereka tidak sungkan untuk berbagi kepada umat Islam. Bentuk lainnya adalah ikut dalam rombongan lebaran, ketika lebaran ada beberapa kelompok rombongan lebaran, yang mana biasanya ketika rombongan tersebut dari awal rombongan sampai akhir rombongan. Umat Budha tersebut juga bersedia untuk membuka rumahnya agar dikunjungi juga. Sikap saling menghormati juga dapat dilihat dari sikap umat Budha dalam membantu ketika ada pelaksanaan keakraban desa seperti jalan santai, ketika desa melaksanakan kegiatan keakraban masyarakat desa biasanya umat Budha membantu dalam mengikuti jalan santai sanagt sedikit karena mereka disibukkan dengan dagangannya.

Berikut ini hasil observasi di lapangan tentang sikap umat Budha dalam kebersamaan peristiwa sosial. Menjenguk orang sakit, ketika ada umat Budha yang sakit yang masih tetangga, sikap umat Islam sekitar bersedia untuk menjenguk.jual beli, pada proses jual beli biasanya tidak ada penghalang untuk membeli atau menjual dagangannya kepada uamt Budha. Proses ini berjalan dengan baik dan lancer di Desa Lubuk Muda.

Sikap bertegur sapa ketika bertangga, dalam bertetangga antara umat Islam dan Budha terbina sikap saling ramah tamah dan peduli, mereka menyempatkna waktu untuk saling bercengkrama di depan rumahnya sekali waktu, walaupun hanya menanyakan kabar. Menghadiri Undangan, umat Islam Desa Lubuk Muda menghadiri undangan yang telah diberikan umat Budha kepadanya. 
Sikap yang ditunju umat Islam dalam menghadiri undangan tersebut dengan menghadiri dan memberi ucapan selamat tanpa mencicipi hidangan yang telah disediakan untuk para tamu, demi menjaga ajaran agama untuk memakan makanan halal. Mengundang ketika ada acara, ketika umat Islam memiliki acara pernikahan ataupun pesta ulang tahun anakanya ia tidak keberatan untuk mengundang umat Budha di acaranya.berbagi makanan maupun pakaian, dalam bertetangga biasanya masyarakat untuk membantu baik dalam bentuk tindakan maupun dana.

Gotong royong bersama, umat Islam mau meluangkan waktunya untuk bergotong royong bersama, serta mau bergabung dengan umat Budha yang juga melaksanak gotong royong bersama, hingga terjalin interaksi yang baik. Menyikapi hari besar agama, ketika umat Budha merayakan hari rayanya umat Islam juga diberi angpau, dan sikap umat islam dengan Uumat Budha saling menghormati dan memberi ucapan selamat hari raya, serta ada beberapa masyarakat yang berkunjung ke rumah umat Budha. Umat Islam di Desa Lubuk Muda pada umumnya memiliki sikap saling memahami dan menghargai terhadap perbedaan yang terjado antara umat Islam dan umat Budha, baik dari segi Bahasa maupun cara berpakaian.

Kita dituntut oleh situasi untuk bekerjasama dengansemua pemeluk agama untuk bersam-sama menjawab tantangan baru yang bertukuran nasional dan internasioanal, antara lain ketidakadilan, terorisme Internasional, kemiskinan structural, sekularsime kiri. Kesemuanya tidak mungkin diatasi oleh satu golongan agama tertentu, tetapi membutuhkan konsolidasi dari segala kekuatan baik moral, spiritual mapupun material dari semua umat beragama .

4. Peringatan Hari Kemerdekaan Indonesia

Pola kerukunan umat Islam dan Budha di Desa Lubuk Muda juga ditandai dengan kekompakan dalam mempersiapakan dan memeriahkan peringatan hari kemerdekaan republik Indonesia pada 17 Agustus. Pada bidang direalsiasikan dengan mengadakan gotong royong bersama dalam menghias desa dengan membersihkan lingkungan dan memasang ornament bendera merah putih di jalan maupun didalam rumah. Seperti keterangan warga desa Lubuk Muda berikut ini:

"kami warga Desa Lubuk Muda
memiliki sikap kompak dan saling
mengingatkan satu sama lain tanpa
memandang perbedaan-perbedaan
yang ada. Kebersamaam atau kedekatan
antara umat Islam dan Budha di desa
ini saya kira karena sikap keterbukaan
apabila ada suatu masalah ataupun
kegiatan. Pada perayaan 17-an kami


biasanya saling mengingatkan ketetangga-tetangga sebelah untuk memasang bendera, dan melihat atraksi atau pawai yang akan diselenggarakan ketika hari peringatan 17-an tersebut."

“perayaan 17-an juga sebagai tempat dalam mempertahankan kerukunan umat beragama yang telah tumbuh sejak dulu di desa ini, karena pada perayaan hari kemerdekaan desa tersebut mengadakan acara yang cukup meriah. Seni- seni yang ditampilkan tidak hanya seni milik orang Islam atau melayu setempat, tapi jug amanampilkna seni milik orang Budha seperti barogsai. Inilah yang menjadi daya tarik masyarakat setempat maupun dari desa tetangga untuk melihat seni atau atraksi yang ditampilkan karena cukup beragam".

Dari hasil wawancara dan observasi dapat penulis ambil kesimpulan bahwa kekompakan serta antusias masyarakat Desa Lubuk Muda dalam memeriahkan hari kemerdekaan hari kemerdekaan negara ini sangat tinggi. Dimana dapat dilihat dari masing-masing pihak berusaha untuk latihan semaksimal mungkin apa yang men jadi khas kebudayaannya untuk ditampilkan. Gotong royong dalam membersihkan dan menghias desa menjadi suasa kemerdekaan dan menjadi tem[pat terjalin interaksi yang bagus sehingga terlihat kerukunan di desa tersebut. Baik umat Islam dan Budha yang ada di desa tersebut mereka saling mengingatkan dan mau berpartisipasi dalam memeperingati hari kemerdekaan ini, seperti hadir dalam undangan upacara, mau ikut pawai, mau menampilkan karya seninya masing-masing. 


\section{DAFTAR PUSTAKA}

Abdul Hamid Ibn' Mu'tadzim, Panduan Lengkap Menikah Islami, 2008.

Abdul Lathif Al-Brigawi, Figh Keluarga Muslim:rahasia mengawetkan babtera rumah tangga, Cet. 2, Penerbit. Amzah, Jakarta, 2014.

Abdurrahman al-jaziri, Al-fiqh 'ala Madzabib Al-Arba'ah, Beirut: Dar Al-fikr, jilid IV, 1986

Al-Hanafy, Jangan Takut Menikah, Mutiara Media, Yogyakarta 2009.

Ali Yusuf As-Subki, Figh Keluarga Pedoman Berkeluarga dalam Islam,Cet. I, Penerbit. Amzah, 2010.

Alkitab, cet.5, edisi 2 (Jakarta: Lembaga Surat Paulus Yang Pertama Kepada Jemaat Di KORINTUS, ayat 7, Surat Paulus Kepada Jemaat Di Galatia, EFESUS , ayat 5, Lembaga Alkitab Indonesia, 1996.

Amir Syarifuddin, Hukum Perkawinan Islam Di Indonesia, Cet. 1, Penerbit. Prenada Media, Jakarta: kencana, 2006.

Amril M., Etika Islam, Cet.1, Penerbit Prenada Media, Jakarta, 2006.

Bahliandi, Etika Pernikahan dalam Perspektif Islam dan Kristen, Skripsi Perbandingan Agama, UIN ArRaniry Banda Aceh,2015.
Beni Achmad Saebeni, Fiqih Munakahad, Bandung: CV Pustaka Setia, 2001.

Departemen Agama RI, Al-Qur'an Dan Terjemah, Jakarta, September 2005.

H.A. Mukhti Ali, Ilmu Perbandingan Agama di Indonesia, Bandung: Mizan, 1992

HR. Bukhari (no. 5066), Kitab An-Nikah; Muslim (no.1402), Kitab AnNikah; dan At-Tirmidzi (no. 1087), Kitab An-Nikah.

Jhon Stott, Isu-isu Global: Menantang Kepemimpinan Kristiani, Komunikasi Bina Kasih/Oms. 1984

Joesoef Sou'yb, Agama-agama Besar Di Dunia, Jakarta: Al-Husna Zikra, 1996,

Jurnal Bimo Aji Protomo, Universitas Atma Jaya Yogyakarta, 09/07/2019. Jam 15:00.

Jurnal Khatulistiwa Journal of Islamic Studies Volume 6 Nomor 1, tahun 2016, di akses 09/07/2019: jam 13:00.

Kartosiswoyo, Kitab Hukum Katolik Semarang: KWI Press, 2006.

Mahmud Yunus, Hukum Perkaninan dalam Islam Jakarta, Al-hidayah, 1968.

Michael Keene, Agama-Agama Dunia, Cet. 5, Penerbit. Kanisius, 2006.

Mohammad Nazir, Metode Penelitian, Bogor: Ghalia Indonesia, 2013.

Muhammad Badrut Tamam, Meniti Indahnya Rumah Tangga Babagia, Sidoarjo, 2009. 
Muhammad Husnul, Bimbingan Perkawinan Islam dan Katolik, Tesis, Yogyakarta: Program Studi. Hukum Islam, Uin Sunan Kalijaga, 2015.

Muhammad Idris Ramuliyo, Asas-Asas Hukum, Jakarta: Sinar Grafika, 1995.

Noorhafizah BT Baharin, Pernikahan Dalam Agama Islam Dan Cittra Wiwaha (Perkawinan) Dalam Agama Hindu (Suatu Studi Komperatif), (Skripsi), Pekanbaru: Uin Suska Riau, 2010.

Sayyid Sabiq, Fiqh Sunnah juz 6, Bandung: Al-Ma'arif, 1990.

Shaleh Bin Ghanim As-Sadlan, Mahar Dan Walimah, Pustaka Al-Kautsar, 1996.

Slamet Abidin dan Aminuddin, Fiqh Munakahat Bandung: CV Pustaka Setia, 1999.

Syamruddin Nasution, Pernikaban Beda Agama Dalam Al-Qur'an,

Syaikh Fuad Shalih, Untuk Yang Akan Menikah dan Telab Menikah, Jakarta, 2009.

Syaikh Kamil Muhammad 'Uwaidah, Fiqih Wanita (edisi lengkap), Cet. I, Penerbit. Pustaka Al-Kautsar, 1998.

Tarpin, Khotimah, Agama Katolik dan Yabudi Sejarab dan Ajaran, Cet. I, Penerbit. Daulat Riau, 2012.
Umar Said, Hukum Islam di Indonesia tentang PerkawinanSurabaya: Cempaka, 2000.

http://www.imanKatolik.or.id/pemahama n-perkawinan-menurutgerejaKatolik.html diakses pada tanggal 12 juni 2019 pukul 21.03.

http://www.kaj.or.id/dokumen/kursuspersiapan-perkawinan-2/hukumgereja-mengenai-pernikahan-

Katolik diakses pada tanggal 23 Mei 2019 pukul 21.25.

http://www.ekaristi.org/khk/index.php?q =1123-1139 diakses pada tanggal 23 Mei 2019 pukul 21.37.

http://

rostiani.Blogsome.com/2018/06/

08/tujuan-pernikahan-dalam-

islam.

http://ms.wikipedia.org/wiki/perkawinan menurut Islam\#Dalil pensyariat an, diakses pada tanggal 23 Mei 2019 pukul 22.37. 